\title{
EQUALITY JUST OVER THE HORIZON: SOVIET GENDER EQUALITY IN LAW AND POLICY ${ }^{1}$
}

\author{
Valdemaras Klumbys \\ (Vilnius University)
}

\begin{abstract}
This article presents an analysis of Soviet law on the family which was valid in Lithuania from 1940, in order to ascertain how it reflected gender equality, how (or if) it was formed, the legal measures the state harnessed in order to create family and gender relation models in various areas of life, and what kind of family and gender policy formed as a result. The law is contextualised in this paper by immersing it in the social reality of its time. This allows us to determine what norms and provisions determined the political and legal resolutions of the Soviet authorities, and to discuss their influence on society. The two most important periods in Soviet gender policy are distinguished. Initially revolutionary and radical in Lithuania, with the aim of changing society to realise its goals, after the 1950s, state policy became more reactive, and adapted to the changed, modernised society and its needs. This paper proposes to see changes to women's situation during the Soviet period not as emancipation, but as (double) mobilisation. The reasons for the stagnation in masculinity in Soviet law and policy, for not keeping up with or adapting to the rapidly changing social reality, are also analysed. The contradictions in Soviet policy regarding the family and gender are shown, where it proved impossible to unambiguously apply 'conservative-liberal' or 'traditional-liberal' distinctions in both policy and reality.
\end{abstract}

KEYWORDS: gender equality, law, Soviet society, social history, Soviet history.

Soviet propaganda constantly boasted that it gave women equal rights to those enjoyed by men, that it liberated women from patriarchal family pressures, and granted them political rights, the chance to work, and so on: the complete emancipation of women had been achieved. In fact, until the 1950s and 196os in the USSR,

${ }^{1}$ This research was funded by the Research Council of Lithuania project 'The Change of Sexual Norms and Behaviour in the Modern Society of Lithuania' (No S-MOD-17-6). 
in many areas of the law at least, women did have more rights than in some West European countries. However, Soviet family and gender policy was certainly very complicated and contradictory:

The Soviet Union has largely been left out of broader discussions in European and global gender history, because the complexities of its gender ideology and outcomes have not easily fitted prevailing models elsewhere - and still do not. ${ }^{2}$

The aim of this article is to analyse Soviet gender equality policy in Lithuania in the legal regulation of family and gender relations, showing the contradictions of this policy. The article is part of broader research, which has meant that Soviet press publications and other source analysis results could be used alongside historiography to discuss, at least briefly, the influence of gender equality policy on society. A more detailed analysis would require a separate paper. Even though Lithuania is the focus of this analysis, the legal regulation of the family was the same across the whole USSR from late 1940 until the 1980 os, with only minor details in the law differing between republics. The union-wide laws discussed in this article were in effect in Lithuania, so this analysis can apply to the whole European part of the USSR.

Although laws do not reflect all the processes taking place in family policy, and much less in society itself, they are nonetheless a kind of matrix determining permissible behavioural boundaries, steering processes that occur in society in one direction or another. In the case of Soviet society, they were a tool aimed at changing (sometimes radically) these kinds of processes, gender relations, family models, etc. Thus, an analysis of these laws allows us to determine the main trends in Soviet family and gender policy.

The historiography on gender in the USSR is very broad and multi-faceted, some of it being devoted to state gender policy. However, when researching the socialisation of gender roles, ${ }^{3}$ or the state's efforts to form a gender identity, ${ }^{4}$ the influence of family

${ }^{2}$ E.L. Fraser, 'Soviet Masculinities and Revolution', Gender in Twentieth-Century Eastern Europe and the USSR, ed. C. Baker (London, 2017), p. 127.

${ }^{3}$ L. Attwood, The New Soviet Man and Woman: Sex-Role Socialization in the USSR (Houndmills, 1990).

${ }^{4}$ E. Zdravomyslova, A. Temkina, 'Gosudarstvennoe konstruirovanie gendera v sovetskom obshchestve', in: Zhurnal issledovanii sotsial'noi politiki, 3-4(2003), pp. 229-321. 
law is analysed only briefly, paying most attention to the Soviet press and people's memories. Up to the collapse of the USSR, due to the lack of sources, the law was analysed much more closely; however, being unable to research society itself, these kinds of studies sometimes only repeated Soviet propaganda. ${ }^{5}$ Papers on Soviet law usually only consider gender equality to be a secondary subject. In this research, the article by Mie Nakachi ${ }^{6}$ is particularly noteworthy, where Soviet demographic policy is analysed through an analysis of the lead-up to creating this kind of legislation.

Dalia Leinartė has gone into the greatest detail in researching family law and gender policy in Soviet Lithuania. ${ }^{7}$ However, her studies only cover the period up to the enactment of the last Soviet family code in 1969. Her comparisons of Soviet law with family law regulations in other European countries from the same period are valuable. But she makes little use of studies of Soviet law by foreign authors, which would allow for a broader interpretation, and some of her statements require correction. Lawyers have also studied Soviet Lithuanian family law, but only the reform movement of Sajūdis times is analysed here. ${ }^{8}$ Soviet family law research ${ }^{9}$ does not go into the real goals of the law, but only repeats ideological postulations on gender equality.

Sources and periodisation. The main sources used in this paper are Soviet laws on marriage and the family, and other related laws. Summaries of the Soviet Lithuanian press were also used, such

${ }^{5}$ For example: H.J. Berman, 'Soviet Family Law in the Light of Russian History and Marxist Theory', in: The Yale Law Journal, 1 (1946), pp. 26-57.

${ }^{6}$ M. Nakachi, 'N. S. Khrushchev and the 1944 Soviet Family Law: Politics, Reproduction, and Language', in: East European Politics and Societies: And Cultures, 1 (2006), pp. 40-68.

7 D. Leinartè, 'Sovietinė lyčių lygybė ir jos įgyvendinimo pradžia Lietuvoje, 1945-1955 m.', in: Liaudies kultūra, 6 (2010), pp. 39-45; D. Marcinkevičienè, 'Teisiniai socialinès paramos šeimai pagrindai sovietinèje Lietuvoje 1945-1970 m.', in: Istorija, 72 (2008), pp. 53-61; D. Marcinkevičienè, 'Civilinè metrikacija ir santuoka sovietinejje Lietuvoje 1940-1969 m.', in: Istorija, 73 (2009), pp. 51-58.

${ }^{8}$ S. Vèlyvis, H. Šadžius, 'Dabartinės Lietuvos šeimos teisės modelio kūrimas tautinio atgimimo ir pirmaisiais nepriklausomybès atkūrimo metais (1988-1992)', in: Jurisprudencija, 69 (2005), pp. 22-35; L.V. Papirtis, H. Šadžius, 'Lietuvos šeimos teisès raida 199o-200o m.: etapai, problemos', in: Socialinis ugdymas, 3 (2013), pp. 10-40.

${ }_{9}^{9}$ P. Dičius, Santuoka ir šeima Tarybų Lietuvoje (Vilnius, 1974); P.V. Rasimavičius, Lietuvos TSR santuokos ir šeimos kodekso komentaras (Vilnius, 1985). 
as the dynamic changes in articles on various family and gender relations issues. Early Soviet laws on marriage, and the first law on marriage and the family, were only used to set the context. ${ }^{10}$ This involved the introduction of civil marriage and easier divorce procedures, the elimination of family wealth inheritance, the equalisation of men's and women's rights, and the rights of children born both in and out of wedlock.

The Russian Law on Marriage, Family and Custody (henceforth C1926), passed in 1926, was particularly relevant to Lithuania. It continued and strengthened the liberalisation of family law: common-law marriage was recognised, and carried the same judicial weight as registered marriages; and divorce was greatly liberalised. However, amendments to C1926 in 1936 made divorce procedures stricter, welfare benefits were introduced for poorer mothers and mothers with a large number of children, the expansion of the network of kindergartens was promised, and penalties for not paying alimony were increased.

Until the occupation, family law in Lithuania was very conservative: the laws of Imperial Russia were still in place, which recognised only church marriages, and so did not allow divorce in practical terms; and the patriarchal family model was maintained. On the other hand, the influence of the West encouraged the emancipation of women, and social pressures existed to see a law on marriage passed legitimising civil marriage, even though this did not happen until 1940. As a result, the Soviet reforms to family law appeared very radical. After Lithuania's occupation, a separate Law on Marriage (henceforth LoM) was valid in Lithuania for some time, which was passed by the Council of Ministers on 9 August, and came into effect on 12 August 1940." This law saw the introduction of civil registry practices in Lithuania. However, it was not valid for long, and by 1 December 1940, C1926 had come into effect. ${ }^{12}$ Lithuania was no

\footnotetext{
${ }^{10}$ 'Kodeks zakonov ob aktakh grazhdanskogo sostoianiia, Brachnom, Semeinom i Opekunskom prave', Sobranie uzakonenii i rasporiazhenii pravitel'stva za 1917-1918 gg. (Moskva, 1942), pp. 1045-74.

${ }^{11}$ 'Santuokos įstatymas', in: Vyriausybès žinios, 15 August 1940, No 725.

${ }^{12}$ RTFSR santuokos, šeimos ir globos įstatymu kodeksas: su pakeitimais iki $1940 \mathrm{~m}$. gruodžio 1 dienos: oficialus tekstas su pastraipsniui susistemintos medžiagos priedu (Kaunas, 1941).
} 
exception in this case. C1926 also applied in Latvia, Estonia, Kazakhstan and Kyrgyzstan. ${ }^{13}$ Claims in historiography that 'Articles from the 1940 Law on Marriage were corrected [after] the war, and included in the USSR Law on Family, Marriage and Custody of 1936 [sic!] and were in effect until the 1969 Law on the Family ${ }^{14}$ are simply misleading.

With Lithuania's reoccupation, C1926 was reinstated. However, this time it was a completely different code. It incorporated the 1941 law on childless and small family taxation, and almost simultaneously with the beginning of Lithuania's reoccupation, on 8 July 1944, a USSR Supreme Soviet decree was passed with a long title hiding its true essence: On the Provision of State Assistance to Pregnant Women, Single Mothers and Mothers of Large Families, the Strengthening of Motherhood and Infancy Care, Qualification for the 'Hero-Mother' Title of Honour and the Establishment of the 'Order of Mother's Glory' and the 'Motherhood Medal'15 (henceforth L1944). These two laws implied a shift towards a cardinally conservative family law: divorce became very restricted, it was no longer possible to determine the paternity of children born out of wedlock by legal means, etc.

The liberalisation of family law only really began after Nikita Khrushchev was ousted from power: divorce procedures were simplified from 1965. Liberalisation became stronger in the Elements for the Law on the Family (henceforth E1968), passed in $1968 .{ }^{16}$ Based on these, the Lithuanian Law on Marriage and the Family (henceforth C1969) was passed in $1969 .{ }^{17}$

${ }^{13}$ O.M. Stone, 'The New Fundamental Principles of Soviet Family Law and Their Social Background', in: International and Comparative Law Quarterly, 2 (1969), p. 392.

${ }^{14}$ Marcinkevičienè, 'Civilinė metrikacija ir santuoka sovietinèje Lietuvoje 19401969 m.', pp. 51, 53.

${ }^{15}$ 'Ukaz Prezidiuma VS SSSR ot o8.07.1944. Ob uvelichenii gosudarstvennoi pomoshchi beremennym zhenshchinam, mnogodetnym i odinokim materiam, usilenii okhrany materinstva i detstva, ob ustanovlenii pochetnogo zvaniia mat'-geroinia i uchrezhdenii ordena materinskaia slava i medali medal' materinstva', 7 August 1944, https://www.lawmix.ru/docs_cccp/3096 (accessed 21 June 2020).

${ }^{16}$ 'TSR Sajungos ir sajunginių respublikų santuokos ir šeimos įstatymų pagrindai', in: LTSR AT ir vyriausybès žinios, No 36 (1968).

${ }^{17}$ Lietuvos Tarybu Socialistinès Respublikos santuokos ir šeimos kodeksas (Vilnius, 1970). 
The more resilient trends towards conservatism in family law from the 1970s were strengthened again in union-wide and republic resolutions passed in 1981 that sought to overcome the demographic crisis in the USSR. ${ }^{18}$

The liberation of women in the USSR from 'kitchen slavery' and gender equality were declared as some of the most important goals of the revolution. The 1936 Constitution stressed that women were being granted equal rights to men in all spheres of life (Article 122). When the 1977 Constitution was being prepared, suggestions were initially made to begin Article 35, devoted to gender equality, with a similar wording: 'Women have rights equal to those of men.' However, this formula received the criticism that men's rights were considered the main ones, while women were merely allowed to have them, which is why the article eventually went as follows: 'Men and women have equal rights. ${ }^{19}$ Discussions such as these show that the formal expression of gender equality was very meticulously considered in the USSR.

However, no further proof is needed to show that Soviet practice could differ quite significantly from formal ideological postulates. Barrington Moore's concept, which identified several ideologies functioning at the same time in a group or organisation, seems quite useful in this case. Formal ideology encompassed publicly expressed goals and the means for achieving these goals, using original ideological doctrine measures. Informal or operational ideology referred to political leaders' 'series of fundamental and often unstated assumptions upon which they all more or less agree'. The third was the 'wide variety of beliefs, shadings, interpretations, and even misunderstandings, held by the rank and file of the organisation.20 ${ }^{20}$ The latter signified the norms and values prevailing in society. I say prevailing, because, of course, there were various, often contradictory, norms that also existed.

\footnotetext{
${ }^{18}$ 'Lietuvos Komunistų partijos Centro komiteto ir Lietuvos TSR Ministrų tarybos nutarimas „Dẻl priemonių valstybės paramai didinti šeimoms, turinčioms vaikų ir demografinei situacijai gerinti respublikoje“', in: LTSR AT ir vyriausybès žinios, No 16 (1981).

${ }^{19}$ L.N. Denisova, Rural Women in the Soviet Union and Post-Soviet Russia (Milton Park, 2010), p. 81.

${ }^{20}$ B. Moore, Soviet Politics - The Dilemma of Power: The Role of Ideas in Social Change (Cambridge, 1950), p. 420.
} 
For the purposes of this paper, the formal and operational levels are understood as collections of values and provisions that are declared openly at a formal level, and are formally masked at the operational. The operational level encompasses norms and values that stood behind the practical policy decisions of the state, often being related to the values of the creators of those policies. Operational ideology was much more responsive to the environment than formal ideology. ${ }^{21}$ Thus, at the operational level, the state could react to political, economic and other needs, as well as to society's values, which were often quite conservative, and not very approving of gender equality right up to the collapse of the USSR. We should bear in mind that apart from the value-based formal, operational and social levels, there was also the practical level, which encompassed political goals, practical policy implementation measures, and external and internal political processes.

This distinction between the various value-based and practical levels allows for a more precise analysis of Soviet law in various areas of gender equality.

Gender equality in the family. Formal gender equality was constantly highlighted in laws, but this was mostly symbolic equality, which, according to Jan Gorecki, expressed equal opportunities for marriage and divorce for both genders (C1926 even equalled the age from which marriage was allowed). It highlighted equality in the rights and duties of spouses and parents, and gave equal ownership of property acquired at the time of marriage, with equal rights to its disposition. ${ }^{22}$

Gender equality was also to be symbolically highlighted by the chance for a woman to keep her own surname after marriage, and for the man to take his wife's surname. This possibility was introduced soon after the revolution. A speech given by a civil registrar in the 1970s in Russia illustrates how this formal equality was implemented at a practical level: a bride could keep her maiden name if she wished, but by taking her husband's surname she would avoid multiple problems at work and with the birth of

${ }^{21}$ Ibid, p. 422.

${ }^{22}$ J. Gorecki, 'Communist Family Pattern: Law as an Implement of Change', in: Law Forum (1972), pp. 129-30. 
their child(ren).$^{23}$ Meanwhile, a man who took his wife's surname would have been nothing less than a sensation.

In addition to such formal declarations of gender equality in Soviet law, there were also cases of clear gender inequality. It appears that conscious efforts were made to avoid referring to gender in the LoM, especially when talking about marital rights and duties. One of the few cases where the husband and the wife are mentioned, and not the word spouse, is Article 72, but this just serves to highlight gender equality: 'The husband and wife agree on which one of them looks after the household.' Interestingly, such provisions about the household did not exist at all in Soviet law, instead giving a rather abstract outline of the equal rights and duties of spouses in the family. Looking at it at the operational level, this would show that the Soviet state, which only formally declared gender equality, did not actually interfere in family matters, and did not seek to realistically change gender roles in the family. This in turn was more likely to mean that taking care of the household duties would not change, and would remain the traditional domain of the woman, which complied with customs widespread in society.

The fact that gender equality was greater in the LoM than in C1926 and in later Soviet laws on the family was probably the result of cardinal changes to the views of the creators of the new law, similar to what existed in Russia immediately after the revolution. The greater gender equality in the LoM was mostly due to the fact that it did not have a specific policy on women, which was so prominent in Soviet law.

Meanwhile, a special approach towards women was already being accentuated in constitutions in the USSR, giving them specific rights and privileges in raising children, which did not apply to men. The 1936 Constitution stressed the particular responsibility of the state regarding the welfare of the mother and child, paid maternity leave, and a wide network of birth centres, nurseries and kindergartens (Article 122). The 1978 Constitution

${ }^{23}$ C.F. Blackman, 'The Civil Sacrament: Law and Practice of Soviet Weddings', in: The American Journal of Comparative Law, 4 (1980), p. 573. 
of the LSSR (as in the USSR Constitution of 1977) listed many more similar rights: the implementation of equal rights ensuring 'special measures for the protection of women's work and health, conditions for women to combine work with motherhood, the legal defence of motherhood and children, material and moral support, including paid leave and other concessions for pregnant women and mothers, and the gradual reduction of work hours for women with young children' (Article 33). This change shows that over 40 years, the role of the woman, whose most important function was motherhood, grew stronger in the law.

This comes as no surprise, since the most important function of the family, from the state's point of view, was reproduction and raising children, which in the USSR was associated exclusively with the woman. In this field, basically from the 193os and throughout almost the whole Soviet period, an active policy was implemented that entrenched the traditional image of the woman as the (family) mother. Soviet family law in general was dominated by a struggle against divorce and maintaining a high birth rate. Even under Stalin, the state did not interfere much in a family's internal relations regarding reproduction or raising children. This is particularly evident in non-legal sources: family issues were covered very rarely in the press. Under Khrushchev, the intensified pressure on collectives and Party organisations, as seen in the press, was mostly limited to either attempts at keeping families on the brink of separation together, or to exacting punishment on cheating spouses (again, upholding the family core), or on semi-enforced marriages in keeping with 'the Party line', where both parents had to be present for the future child.

However, the state did not actually try to change relations between spouses in the family. Although, formally, the state appeared to be trying to reduce the transfer of old, 'bourgeois' values from parents to children, and declared equality between spouses in the family, its actual non-interference supported the traditional gender roles that were widespread in their parents' families. The image of the woman taking care of the household and the children was beneficial to the state's pro-natal policy. This put a halt to changes to gender roles in the family. 
In trying to understand what gender equality declared at a formal level actually meant at the operational level, it would be best to talk not about the emancipation of women, as is almost universally done in historiography, but about their mobilisation, or rather, their double mobilisation. First, the formation of an alliance between the state and women with the passing of L1944 in effect meant one-sided sexual mobilisation: women were urged to have children, even outside wedlock, with the state trying to support single-mother families through welfare allowances, thereby performing the function of a husband and father. ${ }^{24}$ In this way, the state exploited women to satisfy its pro-natal goals. Despite the legal changes of the 196os, this remained Soviet policy until the collapse of the USSR.

Women and work. The state also implemented the work-related, and to an extent social, mobilisation of women. This is precisely what led to the idea of the emancipation of women in the USSR. The fact that the state exploited women is evident from the nature of women's organisations: they were designed exclusively for the mobilisation of women, for the official expression of their confirmed needs, rather than actually working out what women's needs were, or communication. Thus, they were only effective in cases where traditional women's roles needed to change, which no longer suited or interfered with the implementation of the new, official roles of wife, mother and worker. ${ }^{25}$ It is no wonder that the interwar Lithuanian women's movement, women's struggle for their rights and feminism, were described as anarchism after the occupation. ${ }^{26}$ The term itself shows why the women's movement was deemed unacceptable: insubordination to state policy, freedom and unpredictability. Those ruling the USSR needed a predictable, subordinate role for women that would conform with state policy.

${ }^{24}$ For more about L1944 and its importance regarding the situation of women, see: Nakachi, 'N. S. Khrushchev and the 1944 Soviet Family Law'.

${ }^{25}$ A. Stevenson Sanjian, 'Social Problems, Political Issues: Marriage and Divorce in the USSR', in: Soviet Studies, 4 (1991), p. 631.

${ }^{26}$ V. Jurėnienė, 'Sovietinès moters „kūrimas“ Sovietų Lietuvoje ir Sovietų Sajungoje', in: Lyčiu studijos ir tyrimai, 7 (2009), p. 37. 
The Soviet approach to women did not require true gender equality. The research by Dalia Leinartè and Virginija Jurėnienė shows that in the postwar years, Party and government structure functionaries did not support gender equality policy, and women activists could only expect condemnation and derision. ${ }^{27}$ This was how social norms were expressed, but most importantly, they were only opposed at a formal level, and only to the extent that this male opposition interfered with the mobilisation of women, which is evident from provisions at the operational level.

These provisions outlined the importance of the employment of women, where their role could be best fulfilled. The process of turbo-industrialisation required women's participation in the labour force, which is why the old, established behaviour and gender stereotypes had to be 'broken', since they prevented women from joining the workforce. All law codes constantly stressed that a woman could make an independent choice regarding her work and profession, regardless of her husband or her parents. The fact that a woman did not have to live with a husband, as was required in Imperial Russian law, was a testimony to her emancipation, at least at the formal level; but in practice this was mandatory industrialisation, in which workers were often sent to work far away from their families. At the operational level, it again just goes to show the trends in weakening the family core: its primary role was to serve the interests of the state.

Nonetheless, even after the reoccupation of Lithuania, far from all women worked a full day. Soviet constitutions outlined the duty of all able-bodied adults to work (Article 12 of the 1936 Constitution even cited the words of folk wisdom 'He who does not work does not eat'). However, housewives who avoided paid work were not punished. On the other hand, immense economic pressure was put on both spouses throughout the whole Soviet period to work, since for the absolute majority the husband's salary alone was not enough for the family's needs.

${ }^{27}$ For more on this topic, see: Leinartė, 'Sovietinė lyčių lygybė ir jos igyvendinimo pradžia Lietuvoje', pp. 43-44; Jurėnienė, 'Sovietinės moters „kūrimas“ Sovietų Lietuvoje ir Sovietų Sajungoje', pp. 38-39. 
There were other forms of legal pressure that pushed people into employment: the feeling of insecurity indirectly caused by laws aimed at women who were supported by their spouses. For example, C1926 mentioned the duty to support a spouse who was unemployed or could not work (Articles 14-15). However, an explanation by the Supreme Court of the RSFSR in 1935 claimed that a welfare allowance for a spouse like this could only be granted if the person was searching unsuccessfully for work, ${ }^{28}$ while in 1946 the right to receive welfare allowances for an unemployed spouse who was able to work was abolished altogether, ${ }^{29}$ and it was not reinstated in C1969. As such, an unemployed spouse was simply left to the mercy of an employed partner. The only escape from this situation was to work outside the family limits.

For some time after the revolution, the legal pressure only increased: according to the formal understanding of the principle of the equality of spouses, each person's income remained their own property. Thus, women who did not go to formal work and raised children at home would often be left without any property in the event of a divorce. ${ }^{30}$ This provision clearly testifies to the state policy that aimed to force women to join the workforce. The provision changed in C1926: any property coming into the family at the point of marriage was considered as the couple's common matrimonial property, so in the event of divorce, the woman would receive a share. By increasing the protection of women's rights in this way, the state also acknowledged that a woman's work was at home, and that the most important task, giving birth to and raising children, was indeed critical and worth protecting. Perhaps this change in approach can be explained by the fact that the state saw that it would not be able to take over from the family the task of raising children, as the Bolsheviks had believed after

${ }^{28}$ RTFSR santuokos, šeimos ir globos istatymu kodeksas, p. 49.

${ }^{29}$ 'Lietuvos SSR Aukščiausiosios tarybos 1946 m. rugpjūčio 5 d. įsakas „Dèl veikiančių Lietuvos TSR teritorijoje Santuokos, šeimos ir globos įstatymų kodekso ir Civilinio procesinio kodekso pakeitimų', in: LTSR AT žinios, No 17 (1946).

${ }^{30}$ E.L. Johnson, 'Matrimonial Property in Soviet Law', in: International and Comparative Law Quarterly, 4 (1967), p. 1107. 
the revolution, inspired by classic Marxism, ${ }^{31}$ so women had to be encouraged to bear and raise children.

The LoM is interesting in this regard, where Article 75 declares: 'What is acquired during marriage from mutual funds or from mutual partners' work is considered the common property of both spouses', while Articles $73^{-74}$ ensured each spouse the right of ownership to any property brought into the marriage, earned or otherwise gained. These provisions illustrate probably the most important difference between the LoM and C1926. They mean that, in the event of a divorce, a family member who is not working and has no funds of their own (usually the woman responsible for the household and the children) would lose their rights to the property acquired during the marriage: property acquired in marriage would go to whoever had earned it. The provision that came into effect in Lithuania was similar to the one that existed in the USSR up to C1926. Perhaps this was a way of repeating the post-revolutionary Soviet policy that sought to push women into the workforce.

This radical provision was somewhat softened by Article 58 of the LoM, which gave the right to a divorced spouse left without any money to seek it from the former spouse through the courts. The Soviet model of equal ownership of property acquired during marriage, with equal rights to its management, was impossible in capitalist societies at the time, probably due to the particularities of Western business models, ${ }^{32}$ so it could be that the property-related provisions in the LoM were determined by the transition period when legislation had to take into account still-existing businesses and their needs. This is confirmed in the 'income from property and business profit' mentioned in Article 74: features of a purely capitalist economy that were rapidly being eliminated in Sovietised Lithuania, along with private businesses.

Emancipation of women? Employment was meant to transform the woman worker or public activist into a copy of a male worker or public activist, a copy whose self-awareness had nothing to

${ }^{31}$ For more about post-revolutionary Bolshevik attitudes towards the family, see: B.L. Glass, M.K. Stolee, 'Family Law in Soviet Russia, 1917-1945', in:Journal of Marriage and the Family, 4 (1987), pp. 893-896.

${ }^{32}$ Gorecki, 'Communist Family Pattern', pp. 129-13o. 
do with womanhood, and everything to do with simply being a worker. The aim was to erase gender awareness as such in work and public life. Gender identity was to be replaced by a work or Party-related identity. In theory, this could have created real gender equality, whereby everyone would do the same jobs, regardless of their gender. In practice, this was not the case at all. Much has been written about the inconsiderate attitudes of male workers towards female workers in Russia. ${ }^{33}$

As a result, employment was accompanied by the virtual masculinisation of women. ${ }^{34}$ The tension between demands to be as good as a man in the workplace, and the ever-stronger norms for womanhood in the post-Stalin period, was enormous. This was widely written about in the press in the USSR from the 196 os. $^{35}$ However, the Soviet state could not offer any solutions: it needed both, the woman as a mother, and the woman as a worker. It is no wonder, then, that women's movements involving women who worked in typically male jobs (tractor drivers, pilots) that began in the 1930s were not phased out even after Stalin's death. A resolution passed by the LSSR Council of Ministers in 1969 sought to involve more women in qualified jobs in the agricultural sector, to train 'tractor drivers, machinery operators, livestock farm machine operators, electricity installers, renovation tradespeople, builders [...] mostly from among women'. ${ }^{6}$ This was not simply a continuation of Stalinist policy. A shortage of women began to be noticed in Lithuanian villages, as most of the jobs offered on collective farms were for males, which led to a greater disproportion in

${ }_{33}$ D.P. Koenker, 'Men against Women on the Shop Floor in Early Soviet Russia: Gender and Class in the Socialist Workplace', in: The American Historical Review, 5 (1995), pp. 1438-1464; T.G. Schrand, 'Socialism in One Gender: Masculine Values in the Stalin Revolution', Russian Masculinities in History and Culture, (eds. B. Evans Clements, R. Friedman, D. Healey (Houndmills, 2002), p. 201; V.Z. Goldman, Zhenshchiny u prokhodnoi: Gendernye otnosheniia v sovetskoi industrii (1917-1937 gg.) (Moskva, 2010).

${ }^{34}$ N. Roudakova, D.S. Ballard-Reisch, 'Femininity and the Double Burden: Dialogues on the Socialization of Russian Daughters into Womanhood', in: Anthropology of East Europe Review, 1 (1999), p. 22.

${ }^{35}$ Attwood, The New Soviet Man and Woman, pp. 166-169.

${ }^{36}$ 'Lietuvos TSR Ministrų tarybos nutarimas „Dèl platesnio moterų telkimo kvalifikuotam darbui žemės ūkyje“', in: LTSR AT ir vyriausybès žinios, No 5 (1969). 
gender distribution, or, to put it simply, a shortage of brides. Also, men's jobs were more machinery-oriented than those performed by women, as is clear from the list of jobs given in the resolution. Contradictory Soviet policy outcomes also illustrated this fact: the need for manual labour clashed with the worsening demographic situation in the USSR, and the resulting policies offering greater protection for women's reproductive health. Work-related mobilisation clashed with sexual mobilisation.

Thus, actual efforts towards legal emancipation were made in fields where traditional women's roles could have interfered with their mobilisation. We can see here an active and emancipatory state policy. This is most evident in the labour force, and partly in public activity spheres, but the effect of this policy was actually much wider. For example, state educational policy did not discriminate against women (with some exceptions), and ultimately, in the late Soviet period, more women than men were pursuing a higher education. ${ }^{37}$ This is also explained not via formal emancipatory goals, but the practical needs of employment: qualified work required an education.

In fields that were not directly related to work-related and demographic mobilisation (not just in the domestic domain, but also, for example, the influence of gender stereotypes in work relations), gender relations were often left to run their course, with only formal declarations being made in legislation. This passive state position in effect maintained traditional gender roles, especially those of women, beyond the family as well. It suffices to look at the statistics of people holding leading positions: the higher the position, the lower percentage of women holding these posts..$^{8}$

The employment of women functioned rather successfully, and not just as a result of the financial pressure it imposed. The resulting changes to a woman's economic and social situation unavoidably brought about at least the partial mental emancipation of women. This is rather evident from Soviet data, which shows that unmarried women were more politically active, and were

${ }^{37}$ Tarybu Lietuvos moterys: Trumpas statistikos rinkinys, ed. M. Karalienė (Vilnius, 1987), p. 14.

${ }^{38}$ Ibidem, p. 43. 
more inclined to participate in socio-political activities than single men. However, generally speaking, women paid less attention to, or had less time for, political matters. ${ }^{39}$ That is, young women who had escaped patriarchal, traditional families sought compensation for their former subordinated situation by making full use of the new opportunities to be active and to work, and were thus more active in public life and work. Soviet films are full of images of these kinds of women, and interestingly, in the late Soviet period, activists and supervisors were often portrayed as unmarried women or single mothers (Workplace Romance [1977], Moscow does not Believe in Tears [1979] etc).

These kinds of multiple contradictions stop us from unreservedly agreeing with Nakachi's statement that L1944 constructed a new system of women's relations with the state, where the main advantage of women was children and 'the approximate hierarchy of women ordered based on their reproductive contribution to the state, as well as awards for those at the top of this hierarchy, and punishment for those who opposed the system..$^{40}$ This applies only when we are talking about one side of the woman-state relationship, the reproductive one; but after all, there was also the work-related side, as we have seen.

This combination of partial emancipation in the public sphere and traditionalism in the family formed a particular kind of self-awareness among women, which could be termed quasi-feminist, when partially feminist views against the domination of men nonetheless supported the prevailing gender hierarchy and stereotypical gender roles. Even in the law, women's independence and self-respect were indirectly nurtured through their counter position against men. Take the note accompanying the draft of L1944, where the new legal status of a single mother was presented as a newly received freedom, when in actual fact women lost the chance to legally obtain alimony for children from their husbands or to enter the father's surname on their children's documents. ${ }^{41}$

\footnotetext{
${ }^{39}$ Sanjian, 'Social Problems, Political Issues', p. 647.

${ }^{40}$ Nakachi, 'N. S. Khrushchev and the 1944 Soviet Family Law', p. 44.

${ }^{41}$ Ibidem, p. 48.
} 
This shows that the logic behind the legal system was based on an operative way of thinking, which linked a woman's freedom to the non-existence of a husband. It indirectly related masculinity to the subordination of women, inequality and exploitation.

This combination of contradicting policies did not eliminate gender differences in people's consciousness, but only intensified them, fostering an oppositionist attitude towards the opposite gender. In the late Soviet period, women's experiences showed that formal equality was merely a mechanism for exploitation, which is why women highlighted gender differences in the public space..$^{42}$ For some women, this situation aroused a longing for 'real masculinity' and a rejection of the labour force for the benefit of the family and motherhood. ${ }^{43}$ We can understand why this kind of trend emerged: there were two ways out of the double burden loaded on to women's shoulders, to achieve true gender equality in the family as well, or to return to the traditional division of roles by reducing the workload.

A conservative shift. The state was faced with the same dilemma, as the prior policy to distinguish the work-related emancipation of women from emancipation at the household level, and thereby kill two birds with one stone, started to falter in the 1970s and 198 os. Until then, women's work was more important than motherhood, as the decision was made to pursue the double burden rather than reducing the burden on women. When this choice started to signal a demographic catastrophe, policy turned more towards reducing women's workloads. At first, attempts were made to simply strengthen the execution of the already-existing formal laws on workplace safety for women, thereby improving their work conditions. The Women's Work and Household, Motherhood and Child Protection Commission was formed in the Supreme Soviet of the LSSR in $1976,{ }^{44}$ which was involved in controlling the implementation of these laws. Note that the title first of all

${ }^{42}$ Sanjian, 'Social Problems, Political Issues', p. 646.

${ }^{43}$ Attwood, The New Soviet Man and Woman, pp. 170-174.

44 'Lietuvos TSR Aukščiausiosios Tarybos nutarimas „Dèl Lietuvos Tarybų Socialistinès Respublikos Aukščiausiosios Tarybos moterų darbo ir buities, motinystės ir vaikų apsaugos komisijos išrinkimo"', in: LTSR AT ir vyriausybès žinios, No 32 (1976). 
mentions women's work, and only then the household. In terms of the state, women's work was still considered more important than the family.

Separate resolutions were also passed devoted to making work conditions better for women in various fields. One such resolution was passed in 1975 relating to the publishing system. ${ }^{45}$ It was aimed at starting a new campaign to change attitudes towards women's work not just in this field. Further resolutions similar to this appeared in the 1970s and 1980s.

Laws sought to transfer women away from work that involved heavy physical labour, to organise its mechanisation and other ways of making it easier, and to form a list of physically intense or harmful work that women were barred from, going so far as to stop accepting women on to training programmes for such professions. ${ }^{46}$ These kinds of obviously conservative, even discriminatory measures, on one hand aimed at changing the established reality whereby women were often forced to take on physically difficult or harmful work, but on the other, they were meant to protect their reproductive health, as a way of combating the drop in the birth rate.

However, this was obviously not enough, and women's work had to be sacrificed in favour of the reproduction policy. A resolution was passed in 1981 with the resounding title On Measures for Increasing State Support for Families with Children and to Improve the Demographic Situation in the Republic, ${ }^{47}$ which echoed an analogous union-wide resolution. This document was a turning point that reflected the changed demographic policy

${ }^{45}$ 'Lietuvos TSR Aukščiausiosios Tarybos prezidiumo nutarimas „Dèl moterų darbo apsaugos įstatymų vykdymo Lietuvos TSR Ministrų Tarybos valstybinio leidyklų, poligrafijos ir knygu prekybos reikalų komiteto sistemoje"', in: LTSR AT ir vyriausybès žinios, No 36 (1975).

${ }^{46}$ 'Lietuvos TSR Ministrų tarybos ir Lietuvos Respublikinès profesinių sajungų tarybos nutarimas „Dèl papildomų priemonių moterų, dirbančių liaudies ūkyje, darbo sąlygoms gerinti“', in: LTSR AT ir vyriausybès žinios, No 17 (1978).

${ }^{47}$ 'Lietuvos Komunistų partijos Centro komiteto ir Lietuvos TSR Ministrų tarybos nutarimas „Dèl priemonių valstybės paramai didinti šeimoms, turinčioms vaikų ir demografinei situacijai gerinti respublikoje“. 
across the whole USSR (different policies started being implemented in the European and Asian parts of the USSR). ${ }^{48}$ Having openly stated that the demographic situation in the USSR was rather precarious, a conservative policy was further intensified which was meant to help women combine 'participation in production' with motherhood in a better way. The resolution foresaw partially paid leave for looking after a child up to the age of one (35 roubles a month), with another six months of unpaid leave (this term was later extended up to a year) without detriment to her employment history. ${ }^{49}$ Mothers raising children were to be given the chance to work part of the day, or part of the week, according to a changing roster (amendments were made to the Labour Code in January 1988)..$^{5}$

From this point, state policy was aimed at seeing that women would have at least two children. Mothers who had two or more children were given an additional three days of annual leave, priority for receiving annual leave in summer, and another two weeks of additional unpaid leave when the pace of production was lower. Leave for taking care of a sick child was extended to 14 days. $^{51}$ All of this meant that women's work became more expensive than men's, making women less desirable as employees. This kind of policy in the 1980 os basically signalled the gradual end of the universal employment and work-related mobilisation of women; they were forced to become an auxiliary labour force, to be utilised when and where there was a shortage of men.

${ }^{48}$ E. Selezneva, 'Struggling for New Lives: Family and Fertility Policies in the Soviet Union and Modern Russia', in: Center for Economic Institutions Working Paper Series (2016), p. 19.

${ }^{49}$ The respective amendments were made in the Labour Code in 1982: 'Lietuvos TSR Aukščiausiosios Tarybos prezidiumo įsakas „Padaryti pakeitimus ir papildymus Lietuvos TSR darbo įstatymų kodekse"', in: LTSR AT ir vyriausybès žinios, No 34 (1982).

${ }^{50}$ 'Lietuvos TSR Aukščiausiosios Tarybos prezidiumo įsakas „Padaryti pakeitimus ir papildymus Lietuvos TSR darbo įstatymų kodekse", in: LTSR AT ir vyriausybès žinios, No 4 (1988).

${ }^{51}$ They started being applied in late 1987: 'Lietuvos TSR Ministrų tarybos ir Lietuvos Respublikinės profesinių sąungų tarybos nutarimas „Dèl apmokamo laikotarpio sergančiam vaikui slaugyti trukmès pratęsimo“', in: LTSR AT ir vyriausybés žinios, No 31 (1987). 
Of course, this did not lead to immediate changes in real life. The 1981 resolution reveals contradictions in the new family policy, perhaps even a degree of indecisiveness. The further expansion of the network of nurseries, kindergartens, extended day care groups and other children's agencies was planned. There were even intentions to establish pre-school groups where children could spend the whole day and night, even at weekends and on holidays, that is, not spend any time at home at all. These measures were reminiscent of the post-revolutionary plans for the socialisation of children. That is, combined with drawing women away from production, we see the opposite trend, conditions for encouraging greater involvement in production. This is understandable: women made up more than half the working population in the USSR ( 51 per cent across the whole USSR in the 1970s and 1980s, ${ }^{52}$ and 53 per cent in Lithuania in 1984), ${ }^{53}$ and dismissing all these women just for the sake of increasing the birth rate was simply impossible.

This explains why the same resolution from 1981 recognised that the workload in the household had to be reduced for women. Making housework easier and reducing the time needed for housework involved the expansion of the production of ready-tocook meals and the network of cafeterias and cafes, and improving the work of communal and household service enterprises, the production of baby food and other products, and conditions for children's leisure time. Note that in this context, the household was seen as being purely the domain of women, and there was no discussion of increasing men's involvement in that side of life.

Nonetheless, it is difficult to identify unambiguously the policy that started being implemented with this resolution. It showed that the state had reached a dead-end in the universal double mobilisation of women; however, the country's economic demands could not allow any radical policy changes. Yet we can see that there were attempts to move away from the Soviet version of the double 'employment' of women, towards a consistently lib-

${ }^{52}$ Narodnoe khoziaistvo SSSR v 1985 g.: Statisticheskii ezhegodnik (Moskva, 1986), p. 395 .

${ }^{53}$ Tarybu Lietuvos moterys, p. $5^{\circ}$. 
eral mode of employing women, where the state took over part of the burden, offered flexible working hours, the possibility of working part-time, and a comprehensive network of pre-school institutions (this was the path taken by Holland and France ${ }^{54}$ ). Or, more precisely, two ways of combining work and motherhood were offered: one highlighted work (with the child placed in state care), and the other prioritised the family. The application of both tactics was meant to give women a choice between two possibilities. These steps could have actually reduced the double burden; however, they were very costly, as the application of two paths also cost the state twice as much. And the Soviet execution of these approaches was also far from perfect.

Masculinity and gender equality. Soviet policy meant that the institution of motherhood was transformed into a union between the mother and the state, which saw men pushed out of the family; this phenomenon has been discussed by numerous authors analysing masculinity in the Soviet period. ${ }^{55}$ Of course, in traditional families, women and mothers were also more involved in running the household, the children and the family, more so than men or fathers. However, even in patriarchal rural families, the male still exerted enormous authority over other members of the family, and also made decisions and took total responsibility for the family's situation..$^{5}$ In the modernised European urban family, this responsibility remained; however, being the main breadwinner often forced fathers to work far away from their family. ${ }^{57}$

Soviet policy, meanwhile, created a model which could be called nationalised masculinity: the most important masculine roles were those of the worker and soldier, the role in the family as a husband or father was purely formal. However, the man's status remained

\footnotetext{
${ }^{54}$ Marcinkevičienè, 'Teisiniai socialinės paramos šeimai pagrindai sovietinėje Lietuvoje $1945^{-1970 ~ m . ', ~ p . ~} 55$.

${ }^{55}$ For example: Attwood, The New Soviet Man and Woman; A. Rotkirch, The Man Question: Loves and Lives in Late 2oth Century Russia (Helsinki, 200o); E. Zdravomyslova, A. Temkina, 'Gosudarstvennoe konstruirovanie gendera v sovetskom obshchestve', in: Zhurnal issledovanii sotsial'noi politiki, 3-4 (2003), pp. 229-321.

${ }^{56}$ Schrand, 'Masculine Values in the Stalin Revolution', p. 203.

${ }^{57}$ For example: J. Lorentzen, The History of Fatherhood in Norway, 1850-2012 (New York, 2013), pp. 71-8o.
} 
higher than the woman's, both in the family and outside. More attention only started being given to the image of the man as a father in the press from the 1970s, promoting the importance of the father figure to children in magazines such as 'The Family', 'Among the Young' and 'Soviet Woman'. There were even two editions of a book dedicated to fostering masculinity (as well as orientation towards the family), entitled Būk ryras! (Be a Man!)..$^{8}$ This certainly complied with union-wide trends: concern started being shown about a crisis of masculinity.59 However, throughout the whole Soviet period, fathers never had the chance to take paid leave on account of a child's illness; this was allowed only for mothers. Formally, it was a kind of privilege reserved for women, one that the women's movement fought for in its time. However, at the operational level, the man was thereby separated from the family, and was first and foremost associated solely with work; an ill child could not stop him from working.

It would appear that this situation, where the man preserved his higher social status and patriarchal privileges in the family, despite losing patriarchal obligations and responsibilities to take care of the family's welfare, would have served men's interests. Many researchers actually claim this to be the case, ${ }^{60}$ sometimes even calling it a pro-male situation. ${ }^{61}$ Nonetheless, a policy that pushes the husband or father out of the family could hardly be considered as working in men's favour. Men, just like women, were simply being used for the state's goal of meeting its reproduction aims. The enormous scale of alcoholism among men in the USSR was at least partly related to the fact that, being only remotely involved in the family, men lost touch with their close ones.

The constant highlighting of the links between motherhood and the family and children in laws shows that it was not believed that a man could be equal to a woman in terms of running the

${ }^{8}$ S. Griciuvienè, Būk vyras! (Vilnius, 1971); Būk vyras! (Vilnius, 1976).

${ }^{59}$ L. Attwood, pp. 165-169; E. Zdravomyslova, A. Temkina, 'The Crisis of Masculinity in Late Soviet Discourse', in: Russian Social Science Review, 1 (2013), pp. 40-61.

${ }^{60}$ For example: Schrand, 'Masculine Values in the Stalin Revolution', p. 203.

${ }^{61}$ Denisova, Rural Women in the Soviet Union and Post-Soviet Russia, p. 74. 
household or raising the children. Policy in line with this way of thinking was the result: besides working for an employer, the woman had additional duties to motherhood; so in order to achieve total gender equality, the woman would have to be given more specific rights that were not even considered for men. ${ }^{62}$ Men were not encouraged to get involved in housework or child-rearing, as this could have interfered in their employment. That is why it is not at all odd that Lithuania's postwar gender equality policy was 'aimed exclusively at women, and did not involve men in any way'. ${ }^{63}$ That is, men were left out, no real attempts were made to change their awareness; after all, discourses at the formal level always had little effect on people.

Even the highly detailed resolution of 1981 contained only one sentence refering to men: the Communist Youth Central Committee and the Žinija (Knowlede) Society's board had to improve (again) their educational activities, and form 'a responsible attitude among young men towards the family and society, and a respectful attitude towards young women, women, mothers and old people. ${ }^{64}$ That is, no actual work with men was foreseen, and no attempts were made to change their image or model of masculinity. Moreover, there was a basic reliance on the traditional discourse of showing respect towards women, appealing to the traditional image of men as chivalrous knights and gentlemen, and in no way encouraging an understanding of gender equality. In fact, more articles appeared in the press in the 1970s and 1980s about how a man should help his wife at home; only it is unclear whether this was the result of state policy, or simply greater concern in society about the worsening situation in families.

The man as a figure for raising children or feeding the family was never important to the Soviet state from the very beginning. Quite the opposite: the ideological aim of erasing the old, bourgeois family, and especially the patriarchal authority of the father,

${ }^{62}$ Ibidem, p. 81 .

${ }^{63}$ Leinartè, 'Sovietinè lyčių lygybė ir jos igyvendinimo pradžia Lietuvoje', p. 42.

${ }^{64}$ 'Lietuvos Komunistų partijos Centro komiteto ir Lietuvos TSR Ministrų tarybos nutarimas „Dèl priemonių valstybės paramai didinti šeimoms, turinčioms vaikų ir demografinei situacijai gerinti respublikoje“', pp. 455-456. 
could be achieved by liberating the mother and the children from his material and moral dominance (thereby also seeking to reduce the authority of parents over their children by handing this power over to the state). ${ }^{6}$ This was possible only by reducing the man's role in the family. Thus, one of the most important trends in Soviet law on the family was the removal of men from this age-old institution.

Some of this policy actually encouraged gender equality in the family. The authority of parents was restricted: relatives who stopped a woman marrying someone of her own choosing, or who persecuted her for marrying against their will, would be subject to criminal prosecution. In 1929, the Supreme Court of the USSR even equated the murder of a woman on account of her emancipatory actions to a counter-revolutionary crime, an act of terror. In fighting the patriarchal authority of men in the family, women were given the right to start civil court proceedings against their husbands for any injuries they had caused, in accordance with Article 403 of the 1922 Civil Code. In its interpretation of Article 153 on rape in the 1926 Criminal Code, in 1935 the Supreme Court of the USSR indicated that it should also apply when a husband raped his wife, as

marriage in Soviet law is the free choice between a man and a woman to live together, and does not give the man the right [...] to sexual relations, nor does it oblige the woman to offer her body for her husband's satisfaction or sexual passions. $^{66}$

This interpretation is also a testimony to the approach at the operational level (and that prevailing in society) towards the passive participation of women in sexual relations as a means of satisfying their husbands' sexual hunger.

The material dominance of the husband in the family was to be replaced by the state's involvement. Already in 1919, the Soviet state took on responsibility for supporting children and widows, contributing to forming the attitude among men in the cities that the state would take care of their offspring and their wives. ${ }^{67}$ In

\footnotetext{
${ }^{65}$ Berman, 'Soviet Family Law in the Light of Russian History and Marxist Theory', p. $5^{2}$.

${ }^{66}$ Ibidem, p. 49 .

${ }^{67}$ Glass, Stolee, 'Family Law in Soviet Russia, 1917-1945', p. 897.
} 
turn, this attitude among men added to the decline of their role and their authority in the family. However, the USSR did not have enough resources to be able to implement the policy. Thus, at the operational level of the law, what became entrenched was that the man was necessary to the family only as a material provider, and if the state could replace him with welfare allowances, then he was not required at all. This is especially evident in L1944: the fact that the state established and supported the institution of the single mother shows that legislators did not envisage any reason why a woman would want any support, other than financial, from her child's father. ${ }^{68}$ Men were viewed as unnecessary in family life, in housework, and in raising children.

C1926 introduced the opportunity to get a very easy divorce (a request from one of the spouses sufficed for an automatic divorce, without the other partner's participation, sometimes even without their knowledge of the decision). This opportunity seemed to compensate for the husband's removal from the family, by giving him the chance for legal sexual variety and freedom. In turn, this fostered irresponsibility among men. It was mostly men who made the most of this chance to get an easy divorce and legally change partners.

L1944 made divorce a much stricter matter, and halted recognition of the paternity of illegitimate children in the courts. The fact that men no longer had to face the threat of paying alimony for illegitimate children can be considered a kind of compensation for the added difficulties in changing partners, which had been possible under C1926. The fact that men made the most of this opportunity is evident in a secret study conducted in the USSR in 1948. It showed that men would often leave their partners once they found out they were pregnant, and would find new ones. ${ }^{69}$ If we recall the widespread failure to pay alimony (before the war, 40 per cent of court-enforced alimony payments could not be enforced, as the men could not be found $)^{70}$ and the uncomplicated divorce proceedings up to the introduction of L1944, we could

\footnotetext{
${ }^{68}$ Nakachi, 'N. S. Khrushchev and the 1944 Soviet Family Law', p. 55.

${ }^{69}$ Ibidem, p. 65.

${ }^{70}$ Denisova, Rural Women in the Soviet Union and Post-Soviet Russia, p. 74.
} 
say that at the operational level, even after 1944, men's frequent change of partners continued to be viewed quite liberally, and only really served to radicalise the situation.

Courts in the USSR were inclined to interpret the existing laws as much as possible in favour of women, or, more precisely, not so much for women as mothers in particular, to use the available opportunities to bypass the overly strict provisions. In this way, in 1950, the Supreme Court of the USSR decided that Part 3 of Article 42 in C1936, which said that if a husband took custody of a child and later returned it, he had to pay for the child's maintenance if the child's mother happened to die or did not have the money to raise the child; this could apply to parents who were not in a registered marriage when it was known that the father was taking care of the child. Regardless of the fact that this article could only really apply to poorer women, in the 1960 s, as much as 10 per cent of all alimony paid came into this category. ${ }^{71}$

However, this application of the law did not give any other rights to the father; it did not acknowledge his paternity, but only guaranteed alimony for the mother and child. ${ }^{72}$ This indirect way of acknowledging paternity would equate the role of the real father to any other man who had cared for a child for any amount of time. It only further confirmed the operational level provision that fatherhood was completely irrelevant: only the financial contribution made by the father was important in raising a child. Naturally, this would hardly have strengthened any feelings of fatherhood.

Acknowledgement of paternity only became possible indirectly in 1958, through the adoption of an illegitimate child: then, at the stepfather's request, the adopted child could be given the stepfather's surname, or even change the adopted child's first name according to the stepfather's orders, while the step-parents would be entered as the child's parents in birth records. ${ }^{73}$

${ }^{71}$ Ibidem, p. 76 .

${ }^{72}$ W. Gray, 'Scholarship on Soviet Family Law in Perspective', in: Columbia Law Review, 70 (1970), p. 248.

${ }^{73}$ 'Lietuvos TSR Aukščiausiosios tarybos prezidiumo įsakas „Dèl Lietuvos TSR teritorijoje veikiančio Santuokos, šeimos ir globos įstatymų kodekso 6o, 6o, 111 ir 117 straipsnių pakeitimo“', in: LTSR AT ir vyriausybès žinios, No 15 (1958). 
E1968 again allowed the determination of paternity through the courts. This paternity was deemed comparable to the general declaration on acknowledged paternity, that is, the bond between the father and child was considered the same as that between a father and child in a registered marriage. In the draft for the Elements for the Law on the Family, only men who shared a household with the child's mother prior to its birth, or cared for the child after its birth, could be taken to court over paternity disputes. After the debates that arose, the final draft featured another opportunity to determine paternity based on evidence that he knew that he was the child's father. ${ }^{74}$

Unlike prior to L1944, the mother's declaration for determining paternity was no longer enough. That is why acknowledgement of paternity of a child born out of casual relations was impossible if the man did not agree he was the father. That is, compared to the norms in C1926, this law was more on the side of fathers than mothers, thereby partly preserving the impunity of men's extra-marital sexual relations implemented with the changes to the law of the post-war years. In the 196os, Soviet lawyers did not yet know about blood tests already being used in the West that allowed the determination of paternity rather accurately. ${ }^{75}$ That is why only political will determined in whose favour, the father's or the mother's, the law should apply.

Permission in C1969 to acknowledge paternity of a child when one or both parents were married to other people contributed to weakening the family structure. A limitation was put in place whereby the husband of the child's mother had to agree to be given paternity. ${ }^{76}$ In any other case, the man's position in the family would have been completely nullified.

The amendment of 1968 that allowed a father to acknowledge an illegitimate child as his own, as well as one born prior to when E1968 came into effect (the law's validity was backdated), neverthe-

${ }^{74}$ Gray, 'Scholarship on Soviet Family Law in Perspective', p. 248.

${ }^{75}$ Stone, 'The New Fundamental Principles of Soviet Family Law and Their Social Background', p. 401.

${ }^{76}$ Rasimavičius, Lietuvos TSR santuokos ir šeimos kodekso komentaras, p. 72. 
less maintained gender inequality: a man could only acknowledge paternity by a joint agreement with the child's mother (Article 17). This meant that a father could only acknowledge a child as his own with the mother's agreement.

Lawyers believed it was not just the mother who was more important to the child, but also other female relatives. This is evident from the interpretation of Article 70 of C1969 given in the journal Socialistine teise (Socialist Law), where it is indicated that parents had the right to take back children from a person who had taken custody not in line with any law or court agreement, unless the child's transfer to its parents was not in its own interests. An example was given to specify the case, where even if the father had the right to take back a child 'from a grandmother or aunt who had taken custody after the mother's death against the will of the child's father', the court could reject this request from the father. ${ }^{77}$ In this case, it is very clear how the formal level was interpreted in practice, when laws that were seemingly equal regarding each gender would be applied with bias. This interpretation determined the provision at the operational level where the father could potentially act badly towards his child, while a mother could not.

Returning to the link between paternity and alimony in the 196os that existed up to L1944, no legal attempts were made to involve men in the family in other ways: the trend pushing men out of the family continued. The 1955 decree by the Supreme Court of the USSR that legalised abortion also contributed to making men feel unnecessary in the family: the opinion of the child's father, even if he was the legal spouse, was not taken into consideration at all. In the law, fathers were in effect not given any chance to participate in decisions regarding the number of children in the family.

Nonetheless, only in the 1970s did minor policy changes begin to be introduced regarding men. 'With the decree of 1 June 1970, the Soviet government drew attention to and distinguished not only the mother as the guardian and person raising the child, but the father as

\footnotetext{
${ }^{77}$ V. Brazaitytė, 'Vaiko interesų apsaugai', in: Socialistinè teisè, 3 (1979), pp. 5-6.
} 
well. ${ }^{78} \mathrm{He}$ was now relieved from paying his child's costs when it did not attend a childcare institution during the father's regular holiday leave, whereas earlier, only the mother would be relieved from paying these costs. ${ }^{79}$ Such a minor change, however, hardly constituted an attempt to return the father to the family using legal measures.

A slight attempt at integrating the whole family, not just the mother and the child, can be seen in the 1981 resolution whereby families with two or more children were given priority when choosing from available vacation packages, and better conditions for joining allotment associations, and receiving plots of land, building materials or loans for building allotment houses, 'thereby increasing the opportunities for family leisure time and child rearing, and nurturing their contact with nature. ${ }^{80}$ Until then, it was rather difficult for a husband and wife to obtain annual leave or a vacation package at the same time. Leinarte has even stated that the Soviet regime made a special effort to form an image of the family whereby spouses spent their leisure time separately. ${ }^{81}$

The realistic situation of the husband in the family was reflected in an article by a lawyer in 1981, who expressed disappointment with the fact that Lithuanian citizens were not making full use of Article 16 of the Civil Code, which allowed the restriction of the rights of a citizen whose family found itself in difficult material conditions due to the abuse of alcohol and/or narcotic substances. ${ }^{82}$ This usually meant that the salary of the abuser of alcohol would be paid to his wife. As we have seen, Soviet family law in general considered the male in the family to be the incompetent one.

\footnotetext{
${ }^{78}$ Marcinkevičienė, 'Teisiniai socialinès paramos šeimai pagrindai sovietinėje Lietuvoje 1945-1970 m.', p. 59.

${ }^{79}$ 'Lietuvos TSR Ministrų tarybos potvarkis „Dèl tėvų atleidimo nuo mokesčio už vaiko išlaikymą, kai jis nelanko vaikų įstaigos eilinių tẻvo atostogų metu', in: LTSR AT ir vyriausybès žinios, No 16 (1970).

${ }^{80}$ 'Lietuvos Komunistų partijos Centro komiteto ir Lietuvos TSR Ministrų tarybos nutarimas „Dèl priemonių valstybės paramai didinti šeimoms, turinčioms vaikų ir demografinei situacijai gerinti respublikoje“', p. 454.

${ }^{81}$ D. Marcinkevičienè, 'Vyrai, moterys ir sovietinė ideologija', in: Klëja, 7 (2003), http://www.lsc.vu.lt/assets/leidiniai/indexo453.html?show_content_id=599\#_ednref6 (accessed 2106 2020).

${ }^{82}$ J. Nekrašius, 'Vyro atlyginimą ... žmonai', in: Tarybine moteris, 3 (1981), p. III.
} 


\section{Conclusions: gender and modernisation}

Gender equality was one of the most significant characteristics of social and cultural modernisation in the zoth century, inseparably related to the enormous changes taking place in the Western world. The Soviet version of modernisation had a number of features that distinguished it from processes taking place in the West.

One feature of Soviet gender equality law and policy was its contradictions. These are best analysed by distinguishing several levels: formal, which created the framework for actual policies; operational, which was mostly related to the practical needs of the state and the values of policy creators, and the values and provisions of policy implementers, who influenced how laws and policy were implemented; and practical (policy implementation measures, external and internal political and social processes). The varying effects of these levels and their interaction (similarities, deviations and conflicts) are what determined the general Soviet gender equality situation.

What was termed in formal ideology 'the liberation of women from patriarchal slavery in the home', or 'emancipation', was in terms of political goals actually mobilisation by employment. In fields where the traditional roles of women could have interfered with their roles in economic and public activities, serious efforts at legal emancipation were made, which can be seen in active state policy measures to modernise gender relations. This is most evident in the workforce, and partly in the sphere of public activity. That is why the policy implemented regarding women should not be referred to as their emancipation, but rather their mobilisation: attempts were made to change their role and situation to serve the state's economic goals, but not gender equality goals.

However, in areas where women were expected to serve the state's reproduction goals, an attempt was made to preserve their traditional role in the family at the operational level, regardless of the formal declarations about absolute equality in the rights and duties of spouses in the family. Reproduction and raising children were the exclusive domain of women. That is why, in the family space, the most obvious clash was between the conservative re- 
production and modernising emancipatory policies of the state. This double mobilisation (work and reproductive) created a double burden, giving rise to the Soviet superwoman phenomenon.

In this sense, the Soviets in effect tried to create a paradoxical project for the emancipation of women within the framework of the traditional family: the woman was supposed to be a modern equal of men at work and in public life, but she also had to preserve traditional femininity in the family, by being the main actor in raising children and by doing the housework. By taking on the task of mobilising women in this way, the state encouraged their economic (work-related) emancipation. It would be more difficult to talk about cultural emancipation: this took place in education (in the late Soviet period, more women than men graduated from institutions of higher education). However, their self-awareness was only partly emancipated: women practically did not see housework or other family-related tasks as anything but a feminine domain. The progress of social emancipation was very awkward: it was difficult to achieve a status equal to men at work, and even more so in the family, with their husbands.

Both in the USSR and in occupied Lithuania, changes to the situation of women were like revolutions handed down from above, rather than being the result of women fighting for their rights. These changes did not require an emancipatory awareness among women; in fact, the Soviet state's policies interfered in its formation. Instead, quasi-feminist provisions gained ground among women that were very conflictual towards men, which accentuated gender equalities that could not be overcome, yet which also maintained some of the traditional gender stereotypes in their self-awareness, and an understanding of the unavoidability of male dominance.

Men, on the other hand, who had preserved a higher social status than women, along with traditional dominance in the family and work spheres, are often considered in historiography to be the winners in this kind of gender structure. The role of men meant that they were to serve as the state's political instruments: its workforce and its military might.

The role of men did not create the same contradictions as for women, but contradictions in their relations with women. For a 
long time, this policy pushed them outside the institution of the family, transforming them into figures who were either not at all responsible for their family (children), or only necessary as alimony payers, deepening their sole role as breadwinners at the expense of other roles in the family. In addition, encouraging irresponsibility among men created tensions regarding women's increased sense of responsibility, and thus provoked mutual conflict. Also, men were practically left without 'their own' space, unlike women, who could call the family space their own.

Moreover, in line with Anthony Giddens, who believes that modernisation means the self-identity or self-reflection of the individual, ${ }^{8}$ this process admittedly had a much weaker effect on Soviet men than women, who, on account of the significantly changed living conditions and contradictions between their public and private roles, were simply forced to reflect the changes and their situations, and ultimately themselves. In this sense, men were stuck in unreflecting traditional masculinity roles or images that in principle denied gender equality. This is evident from the rather meagre participation of men in discussions about mutual gender relations in the press. Soviet operational ideology and policy only served to encourage these trends. In turn, this situation stopped men adapting to the rapidly accelerating changes happening in society.

Thus, Soviet policy regarding the family and gender was extraordinarily contradictory: it sought to preserve a strong family core, yet women were encouraged to join the workforce, and their financial independence was promoted, two factors that unavoidably contributed to the weakening of the traditional institution of the family. There were no real attempts to create a more modern family model, as no models for masculinity were even suggested that would also allow men to be involved in raising children or doing the housework. Quite the opposite: legislative measures were such that men were pushed out of the family. Equality between men and women was declared; however, the role of the woman

${ }^{8}$ A. Giddens, Modernity and Self-identity: Self and Society in the Late Modern Age (Stanford, 1991). 
and mother as the most important member of the family was clearly distinguished, whereas in society and in the workplace, no real efforts were made to fight gender inequality or traditional gender roles.

Two main periods in Soviet gender policy can be discerned. Until the 1950s, the state made great efforts to influence society in order to realise its goals. Lithuania was practically unaffected by the early stage of revolutionary liberalisation, while the strong move towards strengthening the conservative family model in Lithuania from the 1930s was balanced by the first steps in the emancipation of women after occupation, which took place in the USSR in the 1920 .

Later policy appeared to freeze: no further attempts were made to modernise mutual relations between the genders, nor to work towards the stronger implementation of traditional norms. The changes of the 1950s and 196os were not so much active state efforts to change or form society, but rather the state's reactive adaptation to a changing, modernising society and its needs. It is as if this process took place unwillingly, fearing that changes of one or another kind could harm either its reproduction or its economic policy goals. More distinct expressions of conservative policy appeared only in the 1970s, especially from 1981; however, even they continued to preserve the balance between the work-related and the reproductive role of women.

This shows that it is very difficult to describe family and gender policies implemented in the Soviet Union using ordinary opposing categories, such as 'traditional or modern' and 'conservative or liberal'. In the most general sense, since its very inception, the USSR was viewed as a modernising state that understood gender relations as an active policy object (intervention and regulation). Relations between the genders and their economic and reproductive activities were not the private concern of the related actors, but took on a status of accountability and even obligation to the state.

The multi-faceted and contradictory expectations started to erode traditional family and gender roles and behavioural norms, until eventually a greater source of contradictions, tension and conflict was created in society. It is no wonder that such contradictory 
moves by the state in effect signalled the inefficiency of state policy, which had its own consequences: not being the initiator of a sexual revolution from above, the Soviet state directly and indirectly became an important creator of conditions for a sexual civil war, where gender antagonism grew, and several contradictory gender role and gender relations value and norm systems existed simultaneously. In this regard, processes that took place before 1968 are more important in Soviet Lithuania than those after 1968, as was the case in the West.

\section{Author Details}

Dr Valdemaras Klumbys is an assistant in the Department of Modern History in the Faculty of History at Vilnius University. His fields of interest are Soviet Lithuanian social and cultural history, sexuality and gender studies, the history of the intelligentsia and propaganda.

Address: Department of Modern History, Faculty of History, Vilnius University, 7 Universiteto St, LT-o1513 Vilnius, Lithuania

E-mail: klumbys@gmail.com

\section{Bibliography}

ATTWOOD, Lynne. The New Soviet Man and Woman: Sex-Role Socialization in the USSR (Houndmills, 1990).

BERMAN, Harold J. 'Soviet Family Law in the Light of Russian History and Marxist Theory', in: The Yale Law Journal, Vol. 56, No 1 (1946), pp. 26-57.

BLACKMAN, Charles F. 'The Civil Sacrament: Law and Practice of Soviet Weddings', in: The American Journal of Comparative Law, Vol. 28, No 4 (1980), pp. 555-576.

BRAZAITYTE,, V. 'Vaiko interesų apsaugai', in: Socialistine teisé, No 4 (1979), pp. 3-7.

DENISOVA, Liubov N. Rural Women in the Soviet Union and Post-Soviet Russia (Milton Park, Abingdon, Oxon, 2010).

DIČIUS, Pranas. Santuoka ir šeima Tarybu Lietuvoje (Vilnius, 1974).

FRASER, Erica L. 'Soviet Masculinities and Revolution', in: Gender in Twentieth-Century Eastern Europe and the USSR, ed. C. Baker (London, 2017), pp. 127-40. 
GIDDENS, Anthony. Modernity and Self-identity: Self and Society in the Late Modern Age (Stanford, 1991).

GLASS, Becky L.; STOLEE, Margaret K. 'Family Law in Soviet Russia, 1917-1945, in: Journal of Marriage and the Family, Vol. 49, No 4 (1987), pp. 893-902.

GOLDMAN, Vendi Z. Zhenshchiny u prokhodnoi: Gendernye otnosheniia $v$ sovetskoi industrii (1917-1937 gg.) (Moskva, 2010).

GORECKI, Jan. 'Communist Family Pattern: Law as an Implement of Change', in: Law Forum (1972), pp. 121-36.

GRAY, Whitmore. 'Scholarship on Soviet Family Law in Perspective', in: Columbia Law Review, No 70 (1970), pp. 236-52.

JOHNSON, E. L. 'Matrimonial Property in Soviet Law', in: International and Comparative Law Quarterly, Vol.16, No 4 (1967), pp. 1106-34.

JURĖNIENE, Virginija. 'Sovietinės moters „kūrimas“ Sovietų Lietuvoje ir Sovietų Sajungoje', in: Lyčiu studijos ir tyrimai, No 7 (2009), pp. 36-45.

Tarybu Lietuvos moterys: Trumpas statistikos rinkinys, ed. M. Karalienė (Vilnius, 1987).

'Kodeks zakonov ob aktakh grazhdanskogo sostoianiia, Brachnom, Semeinom i Opekunskom prave', in: Sobranie uzakonenii i rasporiazhenii pravitel'stva za 1917-1918 gg. (Moskva, 1942), pp. 1045-74.

KOENKER, Diane P. 'Men against Women on the Shop Floor in Early Soviet Russia: Gender and Class in the Socialist Workplace', in: The American Historical Review, Vol. 100, No 5 (1995), pp. 1438-1464. https:// doi.org/10.2307/2169865.

LEINARTĖ, Dalia. 'Sovietinė lyčiu lygybė ir jos įgyvendinimo pradžia Lietuvoje, 1945-1955 m.', in: Liaudies kultūra, No 6 (2010), pp. 39-45.

'Teisiniai socialinės paramos šeimai pagrindai sovietinëje Lietuvoje 1945-1970 m.', in: Istorija, Vol. LXXII, No 72 (2008), pp. 53-61.

Vyrai, moterys ir sovietinè ideologija', in: Klëja, No 7 (2003).

'Lietuvos Komunistų partijos Centro komiteto ir Lietuvos TSR Ministrų tarybos nutarimas „Dèl priemonių valstybės paramai didinti šeimoms, turinčioms vaikų ir demografinei situacijai gerinti respublikoje“', in: LTSR AT ir vyriausybès žinios, No 16 (1981).

'Lietuvos SSR Aukščiausiosios tarybos 1946 m. rugpjūčio 5 d. įsakas „Dèl veikiančiu Lietuvos TSR teritorijoje Santuokos, šeimos ir globos įstatymų kodekso ir Civilinio procesinio kodekso pakeitimų', in: LTSR AT žinios, No 17 (1946).

Lietuvos Tarybu Socialistinès Respublikos santuokos ir šeimos kodeksas (Vilnius, 1970). 
'Lietuvos TSR Aukščiausiosios Tarybos nutarimas „Dèl Lietuvos Tarybų Socialistinės Respublikos Aukščiausiosios Tarybos moterų darbo ir buities, motinystės ir vaiku apsaugos komisijos išrinkimo“', in: LTSR AT ir vyriausybès žinios, No 32 (1976).

'Lietuvos TSR Aukščiausiosios tarybos prezidiumo įsakas „Dèl Lietuvos TSR teritorijoje veikiančio Santuokos, šeimos ir globos įstatymų kodekso 6o, 6o, 111 ir 117 straipsnių pakeitimo“', in: LTSR AT ir vyriausybės žinios, No 15 (1958).

'Lietuvos TSR Aukščiausiosios Tarybos prezidiumo įsakas „Padaryti pakeitimus ir papildymus Lietuvos TSR darbo įstatymų kodekse“', in: LTSR AT ir vyriausybès žinios, No 34 (1982).

'Lietuvos TSR Aukščiausiosios Tarybos prezidiumo įsakas „Padaryti pakeitimus ir papildymus Lietuvos TSR darbo įstatymų kodekse“', in: LTSR AT ir vyriausybès žinios, No 4 (1988).

'Lietuvos TSR Aukščiausiosios Tarybos prezidiumo nutarimas „Dèl moterų darbo apsaugos įstatymų vykdymo Lietuvos TSR Ministrų Tarybos valstybinio leidyklų, poligrafijos ir knygu prekybos reikalų komiteto sistemoje“', in: LTSR AT ir vyriausybès žinios, No 36 (1975).

'Lietuvos TSR Ministrų tarybos ir Lietuvos Respublikinės profesinių sajungų tarybos nutarimas „Dèl apmokamo laikotarpio sergančiam vaikui slaugyti trukmès pratęsimo“', in: LTSR AT ir vyriausybès žinios, No 31 (1987).

'Lietuvos TSR Ministrų tarybos ir Lietuvos Respublikinės profesinių sajungų tarybos nutarimas „Dèl papildomų priemonių moterų, dirbančių liaudies ūkyje, darbo sąlygoms gerinti“', in: LTSR AT ir vyriausybės žinios, No 17 (1978).

'Lietuvos TSR Ministrų tarybos nutarimas „Dèl platesnio moteru telkimo kvalifikuotam darbui žemès ūkyje“', in: LTSR AT ir vyriausybès žinios, No 5 (1969).

'Lietuvos TSR Ministrų tarybos potvarkis „Dèl tėvų atleidimo nuo mokesčio už vaiko išlaikymą, kai jis nelanko vaikų îstaigos eilinių tẻvo atostogu metu“', in: LTSR AT ir vyriausybès žinios, No 16 (1970).

LORENTZEN, Jørgen. The History of Fatherhood in Norway, 1850-2012 (New York, 2013).

MARCINKEVIČIENĖ, Dalia. 'Civilinė metrikacija ir santuoka sovietinèje Lietuvoje 1940-1969 m.', in: Istorija, Vol. LXXIII, No 73 (2009), pp. 51-58.

MOORE, Barrington. Soviet Politics - The Dilemma of Power: The Role of Ideas in Social Change (Cambridge, 1950). 
NAKACHI, Mie. 'N. S. Khrushchev and the 1944 Soviet Family Law: Politics, Reproduction, and Language', in: East European Politics and Societies, Vol. 20, No 1 (2006), pp. 40-68.

Narodnoe khoziaistvo SSSR v 1985 g.: Statisticheskii ezhegodnik (Moskva, 1986).

NEKRAŠIUS, Jonas. 'Vyro atlyginimą... žmonai', in: Tarybine moteris, No 3 (1981), p. III.

PAPIRTIS, Leonas Virginijus; ŠADŽIUS, Henrikas. 'Lietuvos šeimos teisès raida 1990-2000 m.: etapai, problemos', in: Socialinis ugdymas, Vol. 35, No 3 (2013), pp. 10-40.

RASIMAVIČIUS, Pranas Vytautas, ed. Lietuvos TSR santuokos ir šeimos kodekso komentaras (Vilnius, 1985).

ROUDAKOVA, Natalia, and Deborah S. BALLARD-REISCH. 'Femininity and the Double Burden: Dialogues on the Socialization of Russian Daughters into Womanhood', in: Anthropology of East Europe Review, Vol. 17, No 1 (1999), pp. 21-34.

RTFSR santuokos, šeimos ir globos istatymu kodeksas: su pakeitimais iki 1940 m. gruodžio 1 dienos : oficialus tekstas su pastraipsniui susistemintos medžiagos priedu (Kaunas, 1941).

SANJIAN, Andrea Stevenson. 'Social Problems, Political Issues: Marriage and Divorce in the USSR', in: Soviet Studies, Vol. 43, No 4 (1991), pp. 629-49.

'Santuokos įstatymas'. Vyriausybès žinios (15 August 1940).

SCHRAND, Thomas G. 'Socialism in One Gender: Masculine Values in the Stalin Revolution', in: Russian Masculinities in History and Culture, eds. B.E. Clements, R. Friedman, D. Healey (Houndmills, 2002), pp. 194-209.

SELEZNEVA, Ekaterina. 'Struggling for New Lives: Family and Fertility Policies in the Soviet Union and Modern Russia', in: Center for Economic Institutions Working Paper Series, No 355 (2016).

STONE, Olive M. 'The New Fundamental Principles of Soviet Family Law and Their Social Background', in: International and Comparative Law Quarterly, Vol. 18, No 2 (1969), pp. 392-423.

'TSR Sajungos ir sajunginių respublikų santuokos ir šeimos įstatymu pagrindai'. In: LTSR AT ir vyriausybės žinios, No 36 (1968).

TSETKIN, Klara. O Lenine: Sbornik statei i vospominanii (Moskva, 1933).

Ukaz Prezidiuma VS SSS ot 08.07.1944 Ob uvelichenii gosudarstvennoi pomoshchi beremennym zhenshchinam, mnogodetnym i odinokim materiam, usilenii okhrany materinstva i detstva, ob ustanovlenii pochetnogo 
zvaniia mat'-geroinia i uchrezhdenii ordena materinskaia slava i medali medal' materinstva (7 August 1944).

VĖLYVIS, Stasys; ŠADŽIUS, Henrikas. 'Dabartinès Lietuvos šeimos teisès modelio kūrimas tautinio atgimimo ir pirmaisiais nepriklausomybès atkūrimo metais (1988-1992)', in: Jurisprudencija, No 69 (2005), pp. 22-35.

ZDRAVOMYSLOVA, Elena; TEMKINA, Anna. 'Gosudarstvennoe konstruirovanie gendera v sovetskom obshchestve', in: Zhurnal issledovanii sotsial'noi politiki, Vol. 1, No 3-4 (2003), pp. 229-321.

\title{
LYGYBĖ UŽ HORIZONOTO: SOVIETINĖ LYČIŲ LYGYBĖ TEISĖJE IR POLITIKOJE
}

\author{
Santrauka
}

\section{VALDEMARAS KLUMBYS}

Tarpukario Lietuvoje iki pat okupacijos veikè itin konservatyvūs cariniai šeimos įstatymai, todèl po okupacijos įsigaliojusi sovietinè šeimos teisẻ buvo revoliucinè, iš esmès keitusi ir šeimos sampratą, ir lyčiu santykius. Tad galima kalbėti apie sovietų vykdytą seksualinę revoliuciją „, „š viršaus“, kuri spartino šeimos santykių modernizavimą konservatyvioje Lietuvos visuomenèje (ypač kaime). Modernizuojanti poveikį Lietuvoje sovietiniai įstatymai darẻ net ir po 1944 m., kai SSRS įvyko konservatyvus šeimos įstatymų pokytis. Nepaisant teisinio lyčių lygybės akcentavimo, gana aiškiai matyti, jog šeimoje lyčių lygybè nebuvo skatinama net įstatymiškai: moteris visų pirma buvo siejama su motinyste ir šeima, o vyras buvo išstumiamas iš šeimos. Valstybė net ir Stalinio valdymo laikais ne itin kišosi ị šeimos vidaus reikalus, buitị, nesiekė pakeisti lyčių vaidmenų šeimoje - svarbiausia šeimoje buvo reprodukcinė ir vaikų auginimo funkcijos, jos daugiausia ir reguliuotos. Dèl tokios padèties buvo palaikomi tradiciniai, iš tẻvų šeimų perimti lyčių vaidmenys, šitaip užkonservuojant dar tarpukarinius šeimos modelius. Realių teisinės emancipacijos pastangų buvo imtasi tose srityse, kur tradiciniai moterų vaidmenys galëjo trukdyti jas mobilizuoti ekonominei ir visuomeninei veiklai, čia valstybės politika buvo aktyvi ir modernizuojanti lyčių santykius. Tokia moterų atžvilgiu vykdyta politika turètų būti įvardijama ne emancipacija, o mobilizacija, kuri buvo dvejopa - seksualinè ir darbinè. Sovietmečiu iš esmès bandyta sukurti paradoksalų moters emancipacijos tradicinès šeimos rẻmuose projektą: moteris turètų tapti moderniai lygiavertė vyrui darbe ir visuomeniniame gyvenime, bet išsaugoti tradicinį moteriškumą šeimoje išlikdama pagrindine (neretai - ir vienintele) vaikų augintoja ir buities darbų atlikejja. Tokia padètis formavo kvazifeministinę moterų savimonę, kai iš dalies feministinès pažiūros, priešiškos vyrų dominavimui, vis dẻlto palaiko dominuojančią lyčių hierarchiją ir stereotipinius lyčių vaidmenis. Apskritai prieštaringų politikų samplaika ne naikino lyčių skirtumus žmonių sąmonėje, o stiprino skirtumų akcentavimą ir ugdè priešišką požiūrị i kitą lytị.

Vyrų išstūmimas iš šeimos faktiškai buvo įtvirtintas įstatymais. Iki pat SSRS žlugimo nebuvo didesnių bandymų keisti vyriškumo vaizdinius ir modelius, kitaip nei moters. Šiokị tokị bandymą integruoti visą šeimą, o ne tik motiną su vaiku galima 
matyti tik devintojo dešimtmečio teisèje. Tokia padėtis lėmè, kad sovietinius vyrus modernizacijos ir individualizacijos procesas paveikè gerokai silpniau nei moteris, kurios dèl smarkiai pasikeitusiu gyvenimo sąlygu ir prieštaravimo tarp viešo ir privataus vaidmenų buvo priverstos reflektuoti vykstančius pokyčius ir savo padėti, kai daugelis vyrų įstrigo nereflektuojamuose tradiciniuose vyriškumo vaizdiniuose, kurie neigė lyčių lygybę iš principo.

Viena iš sovietinès lyčiu lygybès teisès ir politikos ypatybių buvo jos prieštaringumas. Sovietų Sajungos vykdytą šeimos ir lyčių politiką itin sunku apibendrinti paprastomis opozicinèmis - „tradicinë“ ar „moderni“, „konservatyvi“ ar „liberali“ - kategorijomis. Sovietų valstybė, netapusi panašios ị vakarietišką seksualinės revoliucijos iš viršaus iniciatore, tiesiogiai ir netiesiogiai tapo svarbia seksualinio pilietinio karo, kai stiprejja lyčių antagonizmas, o vienu metu egzistuoja kelios prieštaringos lyčių vaidmenų ir lyčių santykių vertybių ir normų sistemos, sąlygų visuomenëje kūrẻja. 